Article

\title{
Revitalization of Trust in Local Government after Wenchuan Earthquake: Constraints and Strategies
}

\author{
Zhichao $\mathrm{Li}^{1, *}$ and Xihan Tan ${ }^{2}$ \\ 1 School of Political Science and Public Administration, East China University of Political Science and Law, \\ Shanghai 201620, China \\ 2 School of Public Administration, University of Electronic Science and Technology of China, Chengdu 611731, \\ China; 2016120301016@std.uestc.edu.cn \\ * Correspondence: 2863@ecupl.edu.cn; Tel.: +86-21-5709-0125
}

Received: 24 September 2018; Accepted: 30 October 2018; Published: 2 November 2018

check for updates

\begin{abstract}
Government trust is an important manifestation of the legitimacy of government, which can reduce the cost of recovery policy implementation and improve the efficiency of reconstruction after natural hazards. Local government is the main force of post-disaster reconstruction in China. The villagers' trust in local government plays an important role in post-disaster reconstruction. Therefore, enhancing the villagers' trust in local government will greatly benefit the resilience of post-disaster reconstruction and the sustainable development of the disaster area. Through analyzing the data collected from a three-year (2009-2012) follow-up survey in Wenchuan after it was struck by an earthquake, we found that villagers' trust toward the local government witnessed a significant decline. Low fairness in policy implementation, dense networks, and particularistic trust were the constraints that hindered the revitalization of trust in the local government. However, the economic improvement had no impact on the "trust in local government". These results suggest that post-disaster recovery should involve more than the reconstruction of the economic performance, such as the fairness of policy implementation and the relief of negative effects of villagers' social networks. Only when considering all of these factors will the sustainability of trust in local government be promoted and the reconstruction efficiency be enhanced in the process of disaster recovery.
\end{abstract}

Keywords: revitalization of trust in local government; Wenchuan earthquake; post-disaster recovery; social network

\section{Introduction}

In recent years, natural disasters have occurred frequently. As an important part of sustainable development, how to deal with post-disaster recovery and carry out post-disaster management have attracted more and more scholars' attention. Emergency management is defined as the process of developing and implementing policies that are concerned with: mitigation, preparedness, response, and recovery [1]. These four phases are equally applicable to post-disaster management. Sustainable development in post-disaster management includes three aspects: economy [2,3], ecology [4], and society [5,6]. Recently, more and more scholars have recognized the importance of non-engineering solutions in post-disaster recovery. Post-disaster recovery involved more than the reconstruction of the built environment; it is framed as a dynamic and uneven political and social process [7]. Many scholars have explored the relationship between government trust and sustainable development after disaster [8,9]. They found that government trust has a significant impact on or a clear relationship with the economy $[10,11]$, ecology [12], and society [13,14]. This study focused on discussing the relationship between trust in local government and post-disaster recovery. 
On 12 May 2008, Wenchuan was struck by an earthquake measuring a magnitude of 8.0 on the Richter scale. Wenchuan is located in rural areas of Sichuan, China. After the earthquake, tens of thousands of villagers were unfortunately killed. The central government and the local government worked immediately on earthquake rescue and organized the reconstruction of houses after disaster.

Post-disaster recovery is a process of reallocating resources and policy implementation [15]. Whether the implementation of the policy is fair and whether the earthquake damage is fully taken into account will inevitably affect the villagers' trust in local government and the productivity of post-disaster reconstruction $[8,16]$. However, villagers' trust toward local government declined after the Wenchuan earthquake [17]. How do villagers' sense of trust toward local government form? Why did trust in local government go down after the disaster? What are the constraints for the revitalization of trust in local government? How do we enhance villagers' trust in local government? Incontrovertibly, there is a practical significance in exploring these issues.

This study is organized as follows. The first section introduces the research questions. Section 2 reviews trust in government and post-disaster recovery as well as related theories of government trust's affecting factors. Based on this, the research hypotheses are put forward. Section 3 is mainly about the research method, showing the data sources, sample size, variable measurement, analysis tools, and statistical models, respectively. Section 4 presents the statistical results and our theoretical analysis. Section 5 features the discussions and conclusions.

\section{Literature Review and Hypotheses}

\subsection{Trust in Government and Post-Disaster Recovery}

The trust in government or political trust refers to the belief or confidence, based on rational judgment, experience, expectation, and so on, toward the government founded on how well the government was operating according to people's normative expectations $[18,19]$. It is an important cornerstone of a country and its political stability $[20,21]$. The uncertainty and skepticism in risk management could be reduced by trust [22]. Trust in government results in cooperation and has been of vital significance in emergency and disaster management [9]. A trustworthy government might actually promote a productive economy, a harmonious and cooperative society, and a democratic government [23], which is beneficial to the sustainability of post-disaster recovery.

However, trust in government will gradually decline during post-disaster recovery. A study [24] showed that in the early post-disaster recovery, one year after the disaster, due to the government's affirmative action and plentiful resources put forth for restoration, people had better life expectations. As a result, it is supposed that they would have a high degree of trust in government and a high tolerance for government action defects. However, in the late stage of the recovery, people began to evaluate the performance of the efforts the government made, which significantly affected the sense of people's trust in government, and a variety of factors would make government trust descend by different degrees.

Different from the "pyramid structure" of trust in the United States (US) government, China presented a "reverse deficit" government trust pattern called "Strong Central, Weak Local" $[25,26]$. Especially after disaster, compared with higher trust in central government, people's trust toward local government is relatively lower and see a downward trend [17]. Han pointed out the pre-disaster distrust, the impolite manners of local officials, and the gap between public expectations and the local government capacity in disaster relief were reasons that impaired people's trust in local government [16]. After the Wenchuan earthquake, villagers' trust toward local government declined, so we selected the earthquake-stricken Wenchuan area as the research object and analyzed the constraints that impeded the revitalization of trust in local government in the process of disaster recovery. Based on our findings, we proposed some strategies. 


\subsection{Various Theoretical Perspectives of Trust in Government}

Current research studies on trust in government are mainly around two issues. First, what are the trends of trust in government and the possible effects or impacts [26-28]? Second, what are the factors that determine trust in government and its generation mechanism [29-31]? For the latter question, based on different theoretical perspectives, researchers have presented various interpretations and theories.

The government performance perspective referred to the idea that society members' trust in government fluctuated along with the overall performance of government, which included economic development, government integrity, social stability, etc. [32]. Many scholars, based on the decline of trust in American and global governments in recent decades, studied what caused this trend. They [33] resisted the assumption that distrust in government happened when government's economic performance could not meet expectations, or community members thought poorly of the government's ability to solve social problems. In addition, whether the politic process was fair and transparent could also be the factor affecting society members' trust in government [34]. Mishler and Rose [30] proposed that whether society members benefited from a government's good performance, especially in the economic sphere, was a major factor causing the degree of trust in government. In other words, the factor affecting people's trust toward government was endogenous, and easily fluctuated with the short-term government performance. For example, the economic voting theory [35] assumed that the economic situation would affect voters' decisions; it suggested that when citizens were satisfied with the economic situation at present, they were inclined to support the current government; otherwise, they were more likely to vote for the opposition parties.

The school of rational choice theory argued that the key of trust's generation mechanism was a member's rational judgment of government performance according to the information he/she collected. However, trust in government could not be formed in short-term, and it was a stable long-term attitude toward politics. Some scholars distinguished the factors influencing trust in government into the short-term and the long-term factors. For example, under the perspective of time, Listhaug distinguished the factors into short-term economic conditions, political figures' integrity issues, and long-term cultural and social interaction factors [36]. The former thought much of short-term economic factors, while the latter put attention on the longer-term community conditions and the social network [37]. Similarly, Norris presented the theories of government performance and the theories of cultural values [38].

From the view of social constructivism, government trust could not be completely attributed to rational judgment, but rather should emphasize the characteristics of the network structure between society members and the emotional factors generated from social interaction. Trust in government was society members' attitudes toward government that formed in the social network via emotional rendering, messaging, and interacting, and these attitudes would be long-lasting [30]. For example, Alesina and Ferrara [39] argued that the "peer effects" might exert an influence on the mechanism of trust; in other words, the interaction among members of society in a small area would generate "social multipliers" [40]. It meant that the society members' social attitudes and evaluations would be amplified and infected on a small scale. Compared with the rational choice theory, the social constructivism regarded the origin of government trust as exogenous, indicating it was born out of the political system.

Since the rise of social capital theory in 1990s, the research literature has attempted to explain trust in the government trust with social capital theory. Putnam's concept of social capital emphasized two elements: first, the social networks that were produced by the autonomous organizations such as communities; and second, the inter-citizen's trust and reciprocity norm. Putnam's basic logic of the generation of trust in government was that people gradually produced reciprocity and cooperation in their social networks by participating in informal groups. Firstly, they formed the particularistic trust within small groups; then, it would gradually extend to general trust. The general trust cultivated by social networks would extend and affect society members' trust in representative institutions 
(government). In short, Putnam believed that trust in the government was the effect projector of social trust in the political sphere [41]. Norris pointed out that Putnam regarded trust in government as the political consequences gradually constructed by members of society in the process of social interaction [42].

\subsection{The Hypotheses from the Perspective of Social Network}

Through the literature review, we found two completely different logical interpretations of trust in government. One began from the rational choice theory, holding the view that trust in government was society members' rational evaluation based on their grasp of the information regarding government performance. The other was from the social constructivism, proposing that trust in government was formed in the social relations network. Social network and social trust played important roles [43]. In other words, government evaluations with perceptual characteristics passed through the social network, and social trust would extend to trust in government.

From the view of government performance, the premise of the theory's logic was trust generated by the rational choice, namely, that people could get relatively adequate government performance information and make a rational judgment on the government's commitment. Yet, this premise is actually very difficult to achieve in reality. Particularly for rural villagers, who in a position of information asymmetry, there are very few opportunities for them to directly contact different government departments. So, how does people's trust toward the government form under the restraint of limited information and limited rationality constraints? Luhmann considered that, with the limitation of experiencing first-hand contact, people's trust of non-interpersonal objects came from the judgment of the medias that they trusted or were familiar with. These medias were often the social networks formed by relatives, acquaintances, colleagues, and other personal contacts [44]. If a person's social network had more strong ties, this network would become relatively closed and denser [45]. On the one hand, such network characteristics were conducive to disseminating political attitudes in a small circle. On the other hand, they easily form large amounts of group pressure, and therefore made the network members have more consistent social attitudes and political attitudes [46-48]. Studies have pointed out that a dense network of emotional relationships can spread and amplify emotional information and attitudes [49,50]. However, it is still difficult to determine whether the evaluation and information on local government that spread across the rural residents' social network was mainly positive or largely negative. For this reason, this study does not propose a directional hypothesis on the relationship between villagers' network characteristics and the trust in local government. Therefore, we just made hypotheses as below:

Hypothesis 1.1. The network scale of villagers' existing social relationships (refer to the emotional relationship) has a significant effect on their trust in local government after disaster.

Hypothesis 1.2. The ratio of villagers' strong ties (the network's proportion of family and acquaintances) to existing social relationships (referring to the emotional relationship) has a significant effect on their trust in local government after disaster.

Through data analysis, Wang [51] found that the majority of people were quite satisfied with the government performance, since they benefited from China's remarkable rapid economic growth in recent years, and this factor produced a more positive impact on annual change of trust in government. As mentioned before, a dense network of emotional relationships would spread and amplify emotional information and attitude $[49,50]$. By this logic, we proposed the following hypothesis for the factors affecting annual changes of trust in local government in the process of disaster recovery:

Hypothesis 1.3. The network scale of villagers' existing social relationships (referring to the emotional relationship) has a significant effect on annual changes in their trust in local government after disaster. 
Hypothesis 1.4. The ratio of villagers' strong ties (the network's proportion of family and acquaintances) to existing social relationships (referring to the emotional relationship) has a significant effect on annual changes of their trust in local government after disaster.

Western scholars have mainly investigated society members' trust in government from the perspectives of government performance and political culture [32,38]. However, in China's countryside, the local government plays an important role in village affairs. The "dense network" formed by villagers and government cadres, namely the close "relationships" networks of power" between villagers and government cadres would have an important impact on villagers' political attitudes, community involvement, and so on [52,53]. Therefore, we proposed the following hypothesis:

Hypothesis 2.1. The ratio of cadres networks' strong ties (the network's proportion of family and acquaintances) has a significant effect on villagers' trust in local government after disaster.

Hypothesis 2.2. The ratio of cadres networks' strong ties (the network's proportion of family and acquaintances) has a significant effect on annual changes of villagers' trust in local government after disaster.

Putnam argued that people in the social network firstly formed the particularistic trust in small groups, and then the trust would gradually extend into a more general trust [41]. The general trust cultivated in a social network would extend and affect the society members' trust in government departments; in other words, the trust in government was shifting from particularistic trust to general trust. Jenny Job, through her quantitative data analysis, pointed out that a higher social trust helped produce a high level of the trust in government and vice versa [54], thereby supporting Putnam's view. In addition, Job's analysis also maintained that high social trust had a positive impact on annual changes of trust in government. Therefore, this study proposed the following hypothesis:

Hypothesis 3.1. Villagers' general trust has a positive effect on their trust in local governments after disaster.

Hypothesis 3.2. Villagers' general trust has a positive effect on annual changes of their trust in local governments after disaster.

\section{Research Method}

\subsection{Data and Sample}

In 2008, the Wenchuan earthquake caused a tremendous loss of life and property for local villagers. It also had a major impact on the local intrinsic social structure and its operational logic. In this sense, the Wenchuan earthquake could be seen as a "breach experiment". According to the views of ethnomethodology, unconventional social status reveals social structure and the operational logic of social relations. It offers sociologists a chance to focus on this issue, regarding the disaster as a huge disturbance force, so that sociologists can study the social structure and operation in unconventional social status [55].

Based on this understanding, a "sustainable rural construction" research team in Sociology Department of Tsinghua University organized and implemented a three-year questionnaire survey in stricken areas of Shifang and Mianzhu, which were among the top 10 hardest hit areas of the Wenchuan earthquake, and gathered three years of follow-up data. The first survey was carried out in May 2009. Due to limited conditions, we did not use the "probability proportional to size sampling" (PPS) method; instead, we used a judgment sample based on the village scale, the severity of the disaster, and the traffic convenience. The survey selected 12 villages, with 33 representative adults from 33 random-selected households per village answering the questionnaire (each household selected one person by using KISH (A questionnaire designed by L. Kish for door-to-door sampling.)). In total, 
558 valid questionnaires were returned in the first survey. The second survey (in November 2010) and third survey (in April 2012) were the follow-up surveys; 313 and 953 valid questionnaires were returned, respectively. In total, 273 samples were involved in each of three surveys.

These questionnaires not only collected the household's disaster situation and recovery data, it also collected data regarding villagers' trust in government, social networks, and other aspects.

\subsection{Variable Measurement}

\subsubsection{Trust in Government}

In the questionnaire, we designed some question items to measure villagers' trust in government. Subjects were required to evaluate to which degree they trusted in the central government, provincial government, municipal government (or county government), township government (or town government), and village committee. These items designed four grading options: "do not trust at all", "do not trust", "more likely to trust", and "trust very much". From the low to high, the options were assigned to one to four points. To be noted, this study regarded the village committee as the government, which contradicts the formal institutional arrangement, but through the pre-survey and field study, we found that the majority of villagers regarded the village cadres as people who were paid by public finances. Taking the "village committee" as the "government" was common sense for most villagers, so in practice, this study regarded the "village committee" as the bottom of the government system (the specific questionnaire can be seen in Appendix A).

In order to operationalize a quantitative analysis of trust in local government easily, we conducted principal component analysis on each result of the three surveys separately. Due to the limited space, only the result in 2009 would be listed. On Table 1, five government hierarchies were divided into two factors (Cronbach's alpha reliability coefficient was 0.737 ). One was the level of respondents' trust in city/county government, town government, and the village committee, which could be called the "trust in local government factor". The other was villagers' trust in the central government and the provincial government, which could be called the "senior trust in government factor". In terms of the hierarchy of Chinese villagers' trust in government [56], from the existing data analysis, scholars found that Chinese villagers' trust in government had two main dimensions: senior trust in government and trust in local government [57]. Our results were more consistent with this.

Table 1. Factor analysis of villagers' trust in government in 2009.

\begin{tabular}{cccc}
\hline Question Item & $\begin{array}{c}\text { Trust in Local } \\
\text { Government Factor }\end{array}$ & $\begin{array}{c}\text { Senior Trust in } \\
\text { Government Factor }\end{array}$ & Total Amount \\
\hline The level of trust in central government & 0.028 & 0.903 & 0.817 \\
The level of trust in provincial government & 0.194 & 0.873 & 0.800 \\
The level of trust in city/county government & 0.820 & 0.159 & 0.699 \\
The level of trust in town government & 0.931 & 0.077 & 0.872 \\
The level of trust in the village committee government & 0.829 & 0.074 & 0.692 \\
Variance contribution rate & $50.024 \%$ & $27.572 \%$ & - \\
\hline
\end{tabular}

The factor analysis in this study used principal component analysis and the variance maximum orthogonal rotation method.

This study only explored the logic of villagers' trust in local government, and therefore only took the "trust in local government factor" as the dependent variable. In order to intuitively analyze the impact of the independent variables on the dependent variable in the regression model, we transformed the numerical score of "trust in local government factor", and then formed a percentile variable with the lowest score of 1 , and the highest score of 100 .

In order to show the changes in villagers' trust in local government more clearly, this study conducted variance analysis on the three-year scores (of percentage) of local governments' trust factors. The results showed that after the Wenchuan Earthquake (from 2009 to 2012), there was a significant decline of the villagers' trust toward local government (the analysis data can be seen in Appendices B and C). 
In China, the state power played an irreplaceable role in the recovery process. In terms of reconstructing and allocating resources, the state's governance function in the existing political structure performed an important role. The central government made use of the financial system and controlled the local government by reallocating tax revenues, specifically, from rich areas to poor regions [58], which is called "counterparts reconstruction". The political task, "completing a three-year reconstruction work in two years" based on a strong political mobilization, greatly promoted the reconstruction process [59]. Consequently, it made a rapid recovery of disaster victim's production and life. However, in such a situation, disaster victims' sense of trust in local governments showed a continuous declining trend. What constraints caused the villagers' low sense of trust toward local government? Is it a rational choice or social construction? This study would explore these questions by quantitative analysis.

\subsubsection{Social Network and Social Trust}

This study operationalized villagers' social networks into two cases: emotional information network and cadres' relation network. The former involved channels of communication and exchanging informal information, gossip, and views between villagers, and the latter was an important factor of villagers' trust in government in Chinese rural society [53]. We used the "name generator" method to measure the emotional information network and the cadres network. When measuring the emotion information network, we mainly asked villagers some private questions, such as for instance, the names of the people who they usually talked to after disaster. When measuring cadres networks, we mainly asked villagers information about the cadres who established friendship with them or helped them. After collecting the mentioned survey data, we calculated the size of the emotional information network, the number of network strong ties, and the number of network strong ties in the cadres network. "Network strong ties" was the proportion of such "strong ties" as relatives and acquaintances in the social network.

A group of researchers represented by Putnam argued that trust in government is a result of social trust extending into political field. To operationalize "trust in society", we used scales to ask villagers the degree of trust in a group of objects and analyzed the results by "principal component factor analysis". We found that two factors from the three-year data of "social trust" could be extracted. One factor was a "general trust" factor (including businessman in the market/trading people, foreigners, etc.), and the other was a "particularistic trust" factor (including relatives, friends, etc.). In order to make it understandable, we made a numerical transformation of all of the factor scores, that was, a percentile variable with a minimum score of one and a highest score of 100.

\subsubsection{The Control Variables}

Except for controlling for some basic demographic variables (such as age and gender), we also controlled for some other variables that might have had an impact on villagers' political trust, including "government performance (the economic improvement and the policy fairness)", "family income per capita", "years of education", and "whether join party (Communist Party of China)".

(1) Government performance: This study mainly discussed the logic of villagers' trust toward local government from the perspective of social networks, and we regarded "government performance" as a control variable. Western scholars generally divide "government performance" into three dimensions: economic development, social stability, and government upright. The economic improvement and the policy fairness are regarded as the most important factors affecting people's evaluation of government performance [60-62]. Based on existing Western research [61,62], this study selected two aspects that concerned villagers most: the economic improvement and the policy fairness, as the operational indicators of "government performance". Specific questions and options regarding economic improvement were: "Compared with last year, to what extent do you think the current situation in your household economic life has improved? Has it greatly improved, increased, decreased, or significantly reduced?" The scores were respectively assigned from four to one. Questions and 
options regarding policy fairness in the implementation process were: "Do you think the government is fair in helping individuals? Was it very fair, a little fair, relatively unfair, or very unfair?" The scores were respectively assigned from four to one. In the analysis, we converted ordinal measures to interval measures, and then put them into the model.

(2) Family income per capita: Previous studies found that people's economic status is an important factor affecting their political attitude; hence, this study took "family income per capita" as one of the control variables.

(3) Years of education: "Education" was also a factor affecting trust in government. For instance, some studies indicated that people with a higher level of education showed a higher degree of trust in government than less educated people $[63,64]$, so this study took the respondent's "years of education" as a control variable.

(4) Party membership: "Party membership" might also have an impact on our trust in government. Since joining the Communist Party of China reflected the people's activism in the political system, to some extent, it also reflected people's trust level in government. This study took "party membership" as a control variable.

To be noted, in order to collect data through the follow-up survey, this three-year survey's respondents remained unchanged, which was good for studying the affecting factors of "trust in local government". The three years of data that were used in this study could be considered repeated measurements of the same group at three time points. In order to facilitate the analysis, we converted the format of the study, and merged them into three-year data. The sample size was $819(273 \times 3)$; such data structures could provide more useful information over time [65]. Table 2 presents the descriptive statistics data of this study, and Table 3 presents the correlation coefficient matrix of data on 2009.

Table 2. The descriptive statistics data.

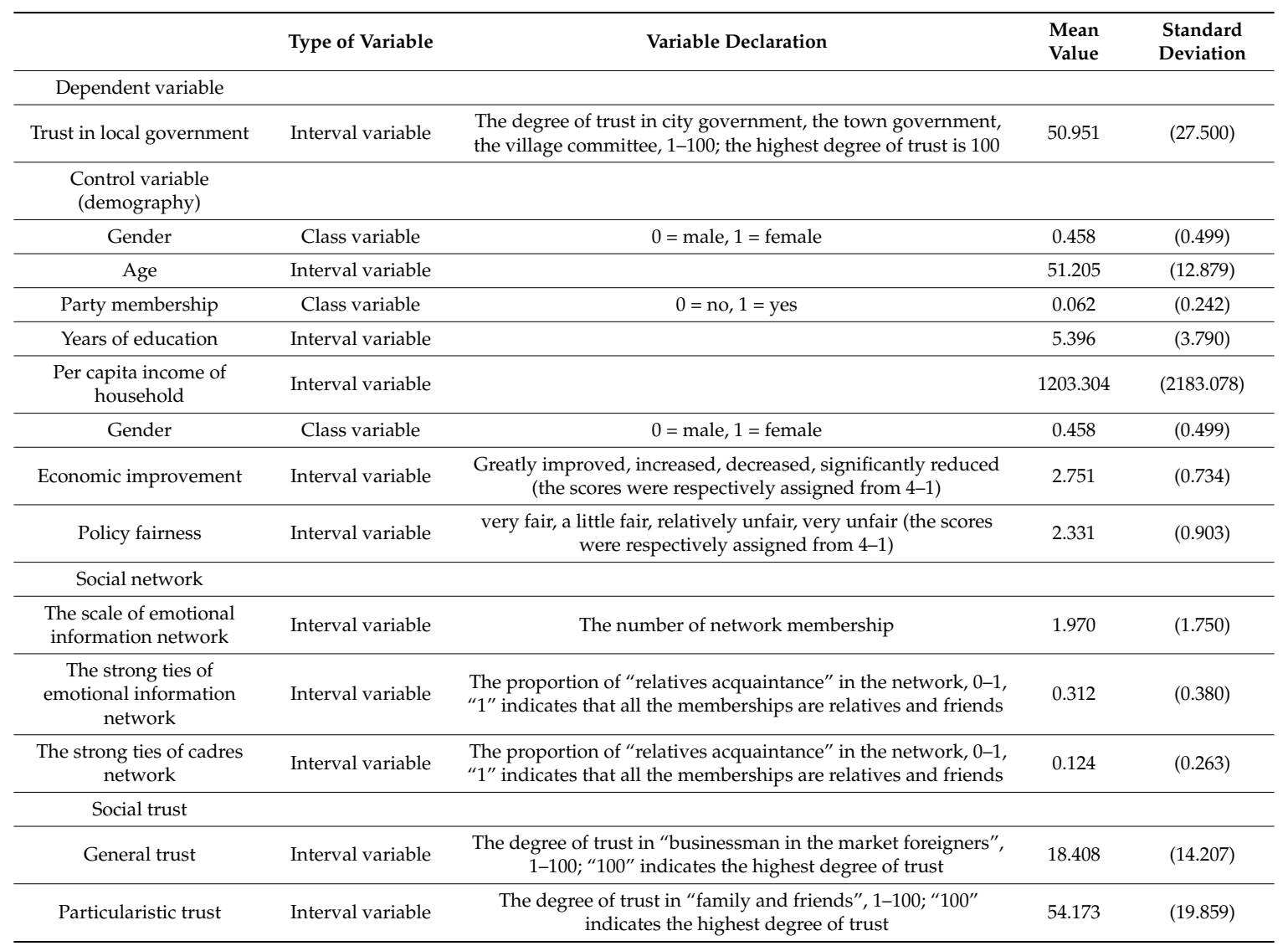


Table 3. The descriptive statistics and the correlation coefficient matrix on 2009.

\begin{tabular}{|c|c|c|c|c|c|c|c|c|c|c|c|c|c|c|c|}
\hline & Mean Value & Standard Deviation & 1 & 2 & 3 & 4 & 5 & 6 & 7 & 8 & 9 & 10 & 11 & 12 & 13 \\
\hline 1. Gender & 0.458 & 0.499 & - & - & - & - & - & - & - & - & - & - & - & - & - \\
\hline 2. Age & 49.872 & 12.834 & $0.154 *$ & - & - & - & - & - & - & - & - & - & - & - & - \\
\hline 3. Party membership & 0.062 & 0.242 & -0.176 ** & 0.083 & - & - & - & - & - & - & - & - & - & - & - \\
\hline 4. Years of education & 5.400 & 3.794 & $-0.175^{* *}$ & $-0.493 * *$ & $0.135 *$ & - & - & - & - & - & - & - & - & - & - \\
\hline 5. Per capita income of household & 6.482 & 1.337 & 0.040 & -0.125 & 0.063 & 0.033 & - & - & - & - & - & - & - & - & - \\
\hline 6. Policy fairness & 2.436 & 0.935 & $0.137 *$ & 0.083 & $0.138 *$ & 0.005 & $0.172 *$ & - & - & - & - & - & - & - & - \\
\hline 7. Economic improvement & 2.955 & 0.624 & 0.066 & 0.075 & -0.030 & -0.059 & $0.452^{* *}$ & 0.098 & - & - & - & - & - & - & - \\
\hline 8. Scale of emotional network & 2.420 & 2.330 & 0.001 & 0.004 & -0.066 & 0.015 & -0.081 & -0.013 & -0.012 & - & - & - & - & - & - \\
\hline 9. Strong ties of emotional network & 0.318 & 0.378 & 0.071 & -0.117 & 0.047 & 0.055 & 0.052 & $0.273^{* *}$ & -0.032 & 0.058 & - & - & - & - & - \\
\hline 10. Strong ties of cadres network & 0.065 & 0.212 & 0.000 & 0.012 & 0.064 & -0.091 & 0.125 & $0.159 *$ & 0.130 & -0.131 * & $-0.158^{*}$ & - & - & - & - \\
\hline 11. General trust & 12.953 & 10.777 & 0.024 & 0.075 & $0.140 *$ & -0.030 & 0.105 & 0.044 & 0.024 & 0.007 & $0.233 * *$ & 0.018 & 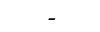 & - & - \\
\hline 12. Particularistic trust & 47.114 & 17.388 & 0.044 & -0.067 & 0.098 & 0.035 & -0.092 & 0.228 ** & $-0.164 *$ & -0.075 & $0.169 *$ & -0.113 & 0.000 & - & - \\
\hline 13. Trust in local government & 59.167 & 24.128 & -0.014 & $0.159^{* *}$ & 0.058 & -0.076 & $0.154^{*}$ & 0.452 ** & $0.165^{\text {** }}$ & -0.198 ** & $-0.463^{* *}$ & $0.304 * *$ & -0.003 & $0.286 * *$ & - \\
\hline
\end{tabular}

* Shows when $p<0.05$ are significant; ** shows when $p<0.01$ are significant. 


\subsection{The Analysis Tools and Statistical Models}

\subsubsection{The Analysis Tools}

The premise of classic linear regression, based on ordinary least squares (OLS), is that the error distribution is normal, independent, and identically distributed [66]. However, our data was the follow-up data that aimed at the same survey respondents for three periods. Therefore, the data error distribution was not independent, and did not apply to classic linear regression. In order to achieve the purpose of analysis, this study used hierarchical linear models (mixed-effects models). Since the measurements of the same individual in different years had the same sample characteristics, the follow-up data that was used in this study could be regarded as having a nested structure. In other words, "measures are nested in individuals", and thus could be analyzed by hierarchical linear models (HLM) [67]. The HLM approach can track the dependent variable's changing trends and explain inter-individual differences.

\subsubsection{Models}

As for the "trust in local government", we first established the unconditional growth model, namely Model 1 . The dependent variable $Y$ represented a factor score (percentage) of villagers' trust in local government. The time variable, year, represented the year of the three investigations, valued 2009, 2010, 2012, respectively. In order to make the intercept have more realistic meanings, this study did a centering treatment to the variable year [68]. The unconditional growth model is a special type of HLM that excludes variables other than the time variable, and is mainly used to demonstrate the trends of the research objects and assess whether the trends vary among the individuals of the sample.

The models were as follows:

Model 1 (the unconditional growth model)

The first layer:

$$
\mathrm{Y}=\beta_{0}+\beta_{1} \times \text { year }+\mathrm{r},
$$

The second layer:

$$
\begin{aligned}
& \beta_{0}=\gamma_{00}+\mu_{0}, \\
& \beta_{1}=\gamma_{10}+\mu_{1},
\end{aligned}
$$

$\beta_{0} \beta_{1}=\gamma_{10}+\mu_{1} \beta_{1}=\gamma_{10}+\mu_{1}$ was the value of the dependent variable at the initial state of an individual's investigation (2009 for this study). $\beta_{1} \beta_{1}=\gamma_{10}+\mu_{1} \beta_{1}=\gamma_{10}+\mu_{1}$ was the slope of the dependent variable of individuals (the annual change or time trend). $\gamma_{00}$ was the overall mean of the dependent variables at the initial state. $\mu_{0}$ was the deviation between the values of individual observations and the dependent variable's overall mean. $\tau_{10}$ was the variance of $\mu_{0}$, reflecting individual differences in dependent variables at the initial state. $\gamma_{10}$ was the individual's average slope of the dependent variable. $\mu_{1}$ was the deviation of the individual slope and the average slope $\left(\gamma_{10}\right) \cdot \tau_{11}$ was the variance of $\mu_{1}$, reflecting the individual's differences in slope (annual change of the dependent variable). As the "unconditional growth model" excludes variables other than the time variable, if $\tau_{10}$ was significant in the model, then the dependent variable at the initial state had significant individual differences; if $\tau_{11}$ was significant in the model, the annual trend of the dependent variable had significant individual differences.

Based on Model 1, we constantly added the independent variable to its second-level model, that was, to discuss the influence of each independent variable on the dependent variable $\left(\beta_{0}\right)$ at the survey's initial state (2009) and the annual change of the dependent variable $\left(\beta_{1}\right)$.

This study firstly took the gender-gender, age-age, years of education-edu, party identification-party, and per capita income of household (of logarithm)-income as the demographic control variables, and then added them into the intercept terms of the first-layer model to build Model 2. We took "years of education" as a fixed pitch variable. This approach compared with 
setting ordinal variable, enabled fewer number of variables into the model, so that the model was more stable. In addition, the "years of education" variable was treated as fixed so that the information from the raw data could get more reservations. The specific practice was as follows: illiterate $=0$, did not graduate elementary education $=1$, level of primary school education $=6$, junior high education $=9$, high school education $=12$, secondary and vocational education $=13$, college education $=15$, undergraduate university education $=17$, graduate education and above $=20$.

Model 2's equation:

The first layer:

$$
\mathrm{Y}=\beta_{0}+\beta_{1} \times \text { year }+\mathrm{r},
$$

The second layer:

$$
\begin{gathered}
\beta_{0}=\gamma_{00}+\gamma_{01} \times \text { gender }+\gamma_{02} \times \text { age }+\gamma_{03} \times \text { party }+\gamma_{04} \times \text { edu }+\gamma_{05} \times \text { income }+\mu_{0}, \\
\beta_{1}=\gamma_{10}+\mu_{1},
\end{gathered}
$$

To test for the differences of explanatory power between rational choice and social constructivism on trust in local government, we gradually added relevant variables into Model 2, and then built other models. Details were as follows:

Based on Model 2, two variables were added to Model 3: improvement in economic life-improvement, the fairness of policy implementation-fairness. These two variables were also control variables, but differed from the demographic control variables in Model 2 in that they were the indicator of "political performance"; thus, we established a separate model.

Model 3's equation:

The first layer:

$$
\mathrm{Y}=\beta_{0}+\beta_{1} \times \text { year }+\mathrm{r}
$$

The second layer:

$$
\begin{gathered}
\beta_{0}=\gamma_{00}+\gamma_{01} \times \text { gender }+\gamma_{02} \times \text { age }+\gamma_{03} \times \text { party }+\gamma_{04} \times \text { edu }+\gamma_{05} \times \text { income }+\gamma_{06} \times \\
\text { improvement }+\gamma_{07} \times \text { fairness }+\mu_{0}, \\
\beta_{1}=\gamma_{10}+\gamma_{11} \times \text { improvement }+\gamma_{12} \times \text { fairness }+\mu_{1},
\end{gathered}
$$

Based on Model 3, Model 4 added three variables of "social networks": the size of emotional information network-size1, the strong tie of the emotional information network-strong tie1, and the strong tie of cadres network-strong tie2.

Model 4's equation:

The first layer:

$$
\mathrm{Y}=\beta_{0}+\beta_{1} \times \text { year }+\mathrm{r},
$$

The second layer:

$$
\begin{gathered}
\beta_{0}=\gamma_{00}+\gamma_{01} \times \text { gender }+\gamma_{02} \times \text { age }+\gamma_{03} \text { party }+\gamma_{04} \times \text { edu }+\gamma_{05} \times \text { income }+\gamma_{08} \times \\
\text { size } 1+\gamma_{09} \times \text { strongtie } 1+\gamma_{010} \times \text { size } 2+\gamma_{011} \times \text { strongtie } 2+\mu_{0}, \\
\beta_{1}=\gamma_{10}+\gamma_{13} \times \text { size } 1+\gamma_{14} \times \text { strongtie } 1+\gamma_{15} \times \text { strongtie } 2+\mu_{1},
\end{gathered}
$$

Model 5's equation:

The first layer:

$$
Y=\beta_{0}+\beta_{1} \times \text { year }+\mathrm{r}
$$


The second layer:

$$
\begin{gathered}
\beta_{0}=\gamma_{00}+\gamma_{01} \times \text { gender }+\gamma_{02} \times \text { age }+\gamma_{03} \text { party }+\gamma_{04} \times \text { edu }+\gamma_{05} \times \text { income }+\gamma_{06} \times \\
\text { improvement }+\gamma_{07} \times \text { fairness }+\gamma_{08} \times \text { size } 1+\gamma_{09} \times \text { strongtie } 1+\gamma_{010} \times \text { strongtie } 2+ \\
\gamma_{011} \times \text { trust } 1+\gamma_{012} \times \text { trust } 2+\mu_{0}, \\
\beta_{1}=\gamma_{10}+\gamma_{11} \times \text { improvement }+\gamma_{12} \times \text { fairness }+\gamma_{13} \times \text { size } 1+\gamma_{14} \times \text { strongtie } 1+\gamma_{15} \times \\
\text { strongtie } 2+\gamma_{16} \times \text { trust } 1+\gamma_{17} \times \text { trust } 2+\mu_{1},
\end{gathered}
$$

This article examined whether there was collinearity in the full model. Due to the statistical software not directly reporting the variance inflation factor (VIF) value of the multilevel regression model, we used the above test methods: a general linear regression model to fit the same model, and then tested its VIF. The results showed that all of the variables were less than five, indicating that there was no significant collinearity.

\section{Results}

\subsection{Statistical Results}

The Dense Network Spread of the Government's Negative Information May Reduce Disaster Recovery Efficiency

Table 4 showed the statistical results. As shown in Table 4, it could be divided into upper and lower parts: fixed effects and random effects. The former one represented the impact of each introduced variable on the dependent variable and its annual change, while the latter illustrated the part of the impact that these mentioned variables could not explain. It should be noted that the multilinear regression model (HLM) has a strong tolerance for the lack of data [69], requiring that the variables in the model have at least one observation. As for processing the missing data of the model in this

\begin{tabular}{|c|c|c|c|c|c|}
\hline \multirow{2}{*}{ Variable } & \multicolumn{5}{|c|}{ Trust in Local Government } \\
\hline & Model 1 & Model 2 & Model 3 & Model 4 & Model 5 \\
\hline \multicolumn{6}{|l|}{ Fixed effects } \\
\hline \multicolumn{6}{|l|}{$\begin{array}{l}\text { Trust in Local Government Mean } \\
\qquad\left(\beta_{0}\right)\end{array}$} \\
\hline Intercept $\left(\gamma_{00}\right)$ & $\begin{array}{c}50.421 * * * \\
(1.247)\end{array}$ & $\begin{array}{c}51.436^{* * *} \\
(8.737)\end{array}$ & $\begin{array}{c}31.520 * * * \\
(8.816)\end{array}$ & $\begin{array}{c}55.352 * * * \\
(8.318)\end{array}$ & $\begin{array}{l}43.261 * * * \\
(9.645)\end{array}$ \\
\hline Sex $(1=$ female $)\left(\gamma_{01}\right)$ & - & $-0.984(2.669)$ & $1.506(2.493)$ & $-0.475(2.429)$ & $1.894(2.213)$ \\
\hline Age $\left(\gamma_{02}\right)$ & - & $0.212 *(0.115)$ & $0.185 *(0.108)$ & $0.155(0.101)$ & $0.147(0.093)$ \\
\hline Party membership $(1=$ Yes $)\left(\gamma_{03}\right)$ & - & $5.312(5.525)$ & $3.158(4.892)$ & $6.003(5.741)$ & $4.573(4.986)$ \\
\hline Years of education $\left(\gamma_{04}\right)$ & - & $0.066(0.387)$ & $0.065(0.373)$ & $0.074(0.366)$ & $0.099(0.344)$ \\
\hline $\begin{array}{l}\text { Per capita income of household } \\
\left(\gamma_{05}\right)\end{array}$ & - & $\begin{array}{l}-1.888^{* *} \\
(0.882)\end{array}$ & $-1.859 *(0.831)$ & $-1.178(0.817)$ & $-1.318(0.775)$ \\
\hline $\begin{array}{l}\text { Improvement in economic life } \\
\qquad\left(\gamma_{06}\right)\end{array}$ & - & - & $0.301(1.668)$ & - & $0.985(1.526)$ \\
\hline $\begin{array}{l}\text { Fairness in policy implementation } \\
\left(\gamma_{07}\right)\end{array}$ & - & - & $8.414^{* * *}(1.231)$ & - & $6.758^{* * *}(1.216)$ \\
\hline $\begin{array}{c}\text { Size of emotional information } \\
\text { network }\left(\gamma_{08}\right)\end{array}$ & - & - & - & $\begin{array}{l}-1.234^{* *} \\
(0.606)\end{array}$ & $\begin{array}{c}-1.337^{* * *} \\
(0.350)\end{array}$ \\
\hline $\begin{array}{l}\text { Strong ties of emotional } \\
\text { information network }\left(\gamma_{09}\right)\end{array}$ & - & - & - & $\begin{array}{c}-13.487^{* * *} \\
(3.034)\end{array}$ & $\begin{array}{l}-11.229 * * * \\
(2.960)\end{array}$ \\
\hline $\begin{array}{l}\text { Strong ties of cadres network } \\
\left(\gamma_{010}\right)\end{array}$ & - & - & - & $\begin{array}{c}10.781^{* * *} \\
(4.123)\end{array}$ & $7.610^{* *}(3.394)$ \\
\hline
\end{tabular}
study, if the variables that were introduced to the model were missing data in all three measurements, the HLM software automatically deleted the case (three-year). According to this approach, 693 samples were eventually input into the model (three-year data used, the sample size is 953).

Table 4. The hierarchical linear model of "trust in local government" affecting factors. 
Table 4. Cont.

\begin{tabular}{|c|c|c|c|c|c|}
\hline \multirow{2}{*}{ Variable } & \multicolumn{5}{|c|}{ Trust in Local Government } \\
\hline & Model 1 & Model 2 & Model 3 & Model 4 & Model 5 \\
\hline \multicolumn{6}{|l|}{ Fixed effects } \\
\hline General trust $\left(\gamma_{011}\right)$ & - & - & - & - & $0.020(0.072)$ \\
\hline Particularistic trust $\left(\gamma_{012}\right)$ & - & - & - & - & $\begin{array}{l}-0.122 * * \\
(0.056)\end{array}$ \\
\hline year $\left(\beta_{1}\right)$ & - & - & - & - & - \\
\hline Intercept (q) & $\begin{array}{c}-4.479 * * * \\
(0.771)\end{array}$ & $\begin{array}{c}-4.491 * * * \\
(0.771)\end{array}$ & $3.757(3.836)$ & $\begin{array}{c}-6.692 * * * \\
(1.399)\end{array}$ & $0.280(5.123)$ \\
\hline $\begin{array}{l}\text { Improvement on economic life } \\
\left(\gamma_{11}\right)\end{array}$ & - & - & $-0.888(1.128)$ & - & $-0.977(1.129)$ \\
\hline $\begin{array}{l}\text { Fairness in policy implementation } \\
\left(\gamma_{12}\right)\end{array}$ & - & - & $\begin{array}{l}-2.452 * * * \\
(0.820)\end{array}$ & - & $\begin{array}{l}-1.974^{* *} \\
(0.855)\end{array}$ \\
\hline $\begin{array}{c}\text { Size of emotional information } \\
\text { network }\left(\gamma_{13}\right)\end{array}$ & - & - & - & $-0.024(0.376)$ & $0.000(0.310)$ \\
\hline $\begin{array}{l}\text { Strong ties of emotional } \\
\text { information network }\left(\gamma_{14}\right)\end{array}$ & - & - & - & $7.205^{* * *}(2.218)$ & $6.843^{* * *}(2.240)$ \\
\hline Strong ties of cadres network $\left(\gamma_{15}\right)$ & - & - & - & $0.793(3.479)$ & $1.546(3.399)$ \\
\hline General trust $\left(\gamma_{16}\right)$ & - & - & - & - & $-0.037(0.070)$ \\
\hline Particularistic trust $\left(\gamma_{17}\right)$ & - & - & - & - & $0.020(0.041)$ \\
\hline $\begin{array}{l}\text { Random effect (variance } \\
\text { component) }\end{array}$ & - & - & - & - & - \\
\hline $\begin{array}{l}\text { Trust in local government mean } \\
\qquad\left(\tau_{10}\right)\end{array}$ & $179.138^{* * *}$ & $170.097^{* * *}$ & $111.469^{* * *}$ & $128.091^{* * *}$ & $83.117^{* * *}$ \\
\hline Year $\left(\tau_{11}\right)$ & $24.618^{* *}$ & $25.123^{* *}$ & $19.155^{* *}$ & $18.757^{*}$ & $18.748^{*}$ \\
\hline Level-1 r & 515.783 & 514.608 & 516.591 & 515.633 & 507.482 \\
\hline Model's total variance & 6230.738 & 6210.350 & 6146.607 & 6152.661 & 6099.213 \\
\hline Parameter & 6 & 11 & 17 & 18 & 21 \\
\hline $\mathrm{N}$ & 693 & 693 & 693 & 693 & 693 \\
\hline
\end{tabular}

\subsection{The Analysis of Statistical Results}

4.2.1. Significant Individual Differences among Villagers' Trust in Local Government in the Annual Change Trend of "Trust in Local Government"

Model 1 was an unconditional growth model. As previously said, there was no other variable except the time variable. This model mainly reflected three trends of the research object, if there was any difference among the samples. From the parameter estimation of Model 1's fixed effects, between 2009-2012, the villagers' trust in the local government tended to decline significantly. In Model 1, the parameter estimation results of random effects showed that there was a significant difference in the villagers' "trust in local government" when we investigated in 2009 , as did the annual trend. This also indicated the feasibility of establishing the hierarchical linear model [68].

\subsubsection{The Demographic Control Variables Had No Significant Effect on "Trust in Local Government"}

There were five control variables in Model 2: gender, age, party membership, years of education, and annual household income per capita (logarithmic). The age and annual household income per capita (logarithmic) had a significant influence on "trust in local government". However, in Model 4 and Model 5, with the inclusion of other explanatory variables, these five control variables did not have a significant effect on "trust in local government". In addition, the estimation results of Model 2's random effect parameters were significant, which indicated that the variables in this model did not explain the individual differences of "trust in local government" and the annual decline trend well. 
4.2.3. "Fairness in Policy Implementation" Had a Significant Effect on the "Trust in Local Government"

The statistical results in Model 3 showed that "the improvement on economic life" did not have a significant effect on the trust in local government and the annual declining trend. A similar result existed in Model 5. However, "fairness in policy implementation" in Model 3, this variable, had a positive effect on trust in local government and an annual declining trend. A similar result existed in Model 5. Therefore, combining the statistical results of Model 3 and Model 5, we found that the degree of improvement in economic life did not affect trust in local government, while the degree of fairness on policy implementation had a significant influence on it.

\subsubsection{The Impact of Villagers' Social Network Factor on Trust in Local Government Shows More} Complex Schemata

The dense network disseminated and imbued the government's negative information, and therefore had a negative impact on trust in local government. In Model 4 and Model 5, the two variables-"scale of emotional information network" and "strong ties of emotional information network" had significant negative effects on the "trust in local government". The "strong ties of emotional information network" significantly enhanced the annual declining trend of "trust in local government". However, the strong ties of the cadre network had a significant positive effect on the "trust in local government". Hence, this study confirmed the validity of hypotheses 1.1, 1.2, 2.1, and 1.4, while hypotheses 1.3 and 2.2 were not proved.

The social trust cannot be extended into trust in local government. In Model 5, as a facet of social trust, "general trust" had no significant effect on the "trust in local government" and its annual change, indicating that the villagers "impersonal" trust, namely the general trust, was difficult to extend into trust in local government. Therefore, hypotheses 3.1 and 3.2 were not confirmed. On the contrary, in Model 5, "particularistic trust" had a significant negative effect on the "trust in local government ". The particularistic trust based on dyads [70] did not only not help generate the "general trust", in contrast, it became an indicator of "small circle" and "dense network".

\section{Discussions and Conclusions}

In the context of China's "relational society", this study focused on the villagers' trust toward local government during disaster recovery, based on the influence of the social network on villagers' evaluation of governmental policy implementation. By analyzing the causality of policy implementation fairness, social networks, and trust in local government, the main conclusions and implications are as follows:

\subsection{Main Findings of This Study}

Fairness of Policy Implementation Promotes Sustainability of Trust in Local Government in the Process of Disaster Recovery

After the Wenchuan Earthquake (from 2009 to 2012), there was a significant decline in the villagers' trust toward local government, and according to our analysis, the policy unfairness is a constraint of revitalization of trust in local government during disaster recovery. Western scholars generally found that the economic development or the economic life improvement have a positive impact on "trust in government" [19,32]; however, the statistical results of this survey did not find that "the economic improvement" has a significant effect on "trust in local government". Conversely, "policy fairness" always has a positive effect on "trust in local government" in the study, suggesting that the governments' implement of rural-related policies fairness and results will significantly affect the villagers' trust toward local government.

The negative effects of the villagers' social network and particularistic trust are constraints that hindered the revitalization of trust in local government. Rural society in China is an "acquaintance 
society", in which people have broad social connections with each other [11]. In China, since most local government's openness of government information needs to be improved, villagers find it difficult to get exact information in a timely manner, so they usually rely on informal social networks to understand the situation. The emotional relationship characterized by "dense networks" and "acquaintance relationships" is an important way to spread and magnify inaccurate information among villagers [71,72]. Especially for the Wenchuan earthquake reconstruction process, the state mobilized substantial resources to finish the hardware construction quickly, and the entire process involved multilevel government departments. Gradually, information opacity, material regulations, and even corruption became hot topics in villagers' daily lives [53]. The dense networks built in villagers spread negative government information that would impede the formation of high government trust and reduce the efficiency of post-disaster reconstruction.

\subsection{Implications of This Study}

Since low fairness will impede the revitalization of trust in local government, local governments should pay special attention to the fairness and transparency of policy implementation for major social events and matters related to the vital interests of villagers. Only when villagers get accurate policy implementation information from their local government can they avoid delay during the golden times of reconstruction due to the spread of rumors in the countryside. This also requires local governments to call for public participation in the process of policy formulation and implementation during disaster recovery. Through public participation, disasters can enhance social capital elements such as trust and community cohesion [73]. At the same time, the local government should take villagers' panics and worries into consideration after disaster, and conduct patient explanations to avoid the spread of rumors in the countryside.

In order to deal with the negative effects of the villagers' social network and particularistic trust, which has hindered the revitalization of trust in local government after disasters in China, we propose the following strategy. The local government should focus on cultivating rural elites and grassroots self-organization, guiding rural public opinion and achieving sustainable rural governance. After the rural tax and fee reform in China, some rural communities showed the characteristics of "individualization" and "publicity-lacked" [74]. Therefore, it is necessary for local governments to cultivate rural elites and communities' social capital and guide outstanding young people to take root in the countryside. In this way, they will gradually become the link between the country and the villagers, which not only promotes the joint force between local government and villagers during the post-disaster reconstruction, but also builds a solid foundation for good governance in the countryside.

\subsection{Limitations of This StudyS}

This research was a follow-up investigation that was limited to 10 villages after the Wenchuan earthquake. These samples were easily "variable controlled" regarding studying the social attitudes to clarify the affecting factors and causal logic of the trust in government. Yet, it was difficult to conduct random sampling with these samples; thus, the conclusions of this study were subject to certain restrictions regarding the representation.

Author Contributions: Conceptualization, Z.L.; Methodology, Z.L.; Validation, Z.L. and X.T.; Formal Analysis, X.T. Writing—original draft preparation, Z.L.; Writing—review and editing, X.T., Supervision, Z.L.

Funding: The research was funded by Tsinghua University - Nomura Research Institute China Research Center Research Program (NO.041913016)

Acknowledgments: I am grateful for H.J., H.X., L.L. and C.L. for their great help in writing on the early draft.

Conflicts of Interest: The authors declare no conflict of interest. 


\section{Appendix A}

Questionnaire of Section 3.2.1

\begin{tabular}{|c|c|c|c|c|c|}
\hline PR03 & $\begin{array}{l}\text { In a society, people may trust some people more. } \\
\text { How much do you trust these people or } \\
\text { organizations in the following list? Please choose } \\
\text { "do not trust at all", "do not trust", "more likely } \\
\text { to trust", or "trust very much" through circling } \\
\text { one of the options. }\end{array}$ & \multicolumn{4}{|c|}{$\begin{array}{l}\text { 1. Do not trust at all } \\
\text { 2. Do not trust } \\
\text { 3. More likely to trust } \\
\text { 4. Trust very much }\end{array}$} \\
\hline A & Your family members & 1 & 2 & 3 & 4 \\
\hline $\mathrm{P}$ & Your best friends & 1 & 2 & 3 & 4 \\
\hline B & Neighborhoods & 1 & 2 & 3 & 4 \\
\hline $\mathrm{C}$ & Businessmen in the market/trading people & 1 & 2 & 3 & 4 \\
\hline $\mathrm{D}$ & Strangers & 1 & 2 & 3 & 4 \\
\hline $\mathrm{E}$ & Central government & 1 & 2 & 3 & 4 \\
\hline $\mathrm{F}$ & Provincial government & 1 & 2 & 3 & 4 \\
\hline G & Municipal government (or country government) & 1 & 2 & 3 & 4 \\
\hline $\mathrm{H}$ & Township government (or town government) & 1 & 2 & 3 & 4 \\
\hline I & Village committee & 1 & 2 & 3 & 4 \\
\hline Q & Many villagers in the village & 1 & 2 & 3 & 4 \\
\hline $\mathrm{S}$ & Professors/scholars & 1 & 2 & 3 & 4 \\
\hline $\mathrm{T}$ & Lawyers & 1 & 2 & 3 & 4 \\
\hline $\mathrm{J}$ & Policemen & 1 & 2 & 3 & 4 \\
\hline K & Doctors & 1 & 2 & 3 & 4 \\
\hline $\mathrm{L}$ & $\begin{array}{l}\text { Domestic broadcasts/The news in the TV or } \\
\text { news studies }\end{array}$ & 1 & 2 & 3 & 4 \\
\hline M & Judges/Courts & 1 & 2 & 3 & 4 \\
\hline $\mathrm{N}$ & Foreigners & 1 & 2 & 3 & 4 \\
\hline $\mathrm{O}$ & Volunteers & 1 & 2 & 3 & 4 \\
\hline
\end{tabular}

\section{Appendix B}

Table A1. The inspection differences in "trust in local government" between annual groups.

\begin{tabular}{cccccc}
\hline Origin & Sum of Squares & df & The Mean Square & $\mathbf{f}$ & Sig. \\
\hline Correction model & 31582.040 & 2 & 15791.020 & 22.001 & 0.000 \\
Intercept & 2030025.633 & 1 & 2030025.633 & 2828.371 & 0.000 \\
Year & 31582.040 & 2 & 15791.020 & 22.001 & 0.000 \\
Error & 560552.415 & 781 & 717.737 & - & - \\
total correction & 592134.455 & 783 & - & - & - \\
\hline
\end{tabular}

The dependent variable: trust in local government (of percentage), $\mathrm{R}$ squared $=0.053$ (adjusted R square $=0.051$ ).

\section{Appendix C}

Table A2. "Trust in local government" multiple comparison by year.

\begin{tabular}{cccccccc}
\hline & & & & & \multicolumn{3}{c}{$\mathbf{9 5}$ Confidence Interval } \\
\hline & (I) Year & (J) Year & $\begin{array}{c}\text { Average } \\
\text { Arithmetic (I-J) }\end{array}$ & $\begin{array}{c}\text { Standard } \\
\text { Error }\end{array}$ & Sig. & $\begin{array}{c}\text { The Low } \\
\text { Limit }\end{array}$ & $\begin{array}{c}\text { The } \\
\text { Ceiling }\end{array}$ \\
\hline LSD & 2009 & 2010 & $9.5438^{*}$ & 2.36304 & 0.000 & 4.9051 & 4.9051 \\
- & - & 2012 & $15.1827^{*}$ & 2.31220 & 0.000 & 10.6438 & 19.7216 \\
- & 2010 & 2009 & $-9.5438^{*}$ & 2.36304 & 0.000 & -14.1824 & -4.9051 \\
- & - & 2012 & $5.6389^{*}$ & 2.36093 & 0.017 & 1.0044 & 10.2734 \\
- & 2012 & 2009 & $-15.1827^{*}$ & 2.31220 & 0.000 & -19.7216 & -10.6438 \\
- & - & 2010 & $-5.6389^{*}$ & 2.36093 & 0.017 & -10.2734 & -1.0044 \\
\hline
\end{tabular}

${ }^{*}$ Indicates average arithmetic significant at the level of 0.05 . 


\section{References}

1. Petak, W.J. Emergency Management: A Challenge for Public Administration. Public Adm. Rev. 1985, 45, 3-7. [CrossRef]

2. Peng, Y.; Li, X.; Huang, L.; Jiang, S.; Xu, Y.; Lai, Y. Risks of Developing Concentrated Rural Settlement after the Wenchuan Earthquake in China. Sustainability 2018, 10, 1569. [CrossRef]

3. Huang, L.; Wang, L.; Song, J. Post-Disaster Business Recovery and Sustainable Development: A Study of 2008 Wenchuan Earthquake. Sustainability 2018, 10, 651. [CrossRef]

4. Rojas, O.; Zamorano, M.; Saez, K.; Rojas, C.; Vega, C.; Arriagada, L.; Basnou, C. Social Perception of Ecosystem Services in a Coastal Wetland Post-Earthquake: A Case Study in Chile. Sustainability 2017, 9, 1983. [CrossRef]

5. Fujioka, T. Disaster risk reduction in regional areas and schools from the viewpoint of education for sustainable development. Quat. Res. 2016, 55, 175-183. [CrossRef]

6. Cui, K.; Han, Z.; Wang, D. Resilience of an Earthquake-Stricken Rural Community in Southwest China: Correlation with Disaster Risk Reduction Efforts. Int. J. Environ. Res. Public Health 2018, 15, 407. [CrossRef] [PubMed]

7. Tierney, K.; Oliver-Smith, A. Social dimensions of disaster recovery. Int. J. Mass Emerg. Disasters 2012, 30, 123-146.

8. Li, Z.; Sun, Z.; Fang, Z. Policy Fairness, Social Networks and Villagers' Trust in Local Governments-Based on Three Years Follow-up Survey Data Gathered after Wenchuan Earthquake. J. Public Manag. 2015, 12, 47-57. (In Chinese)

9. Han, Z.; Lu, X.; Hörhager, E.I.; Yan, J. The effects of trust in government on earthquake survivors' risk perception and preparedness in China. Nat. Hazards 2017, 86, 437-452. [CrossRef]

10. Vilhelmsdóttir, S.; Kristinsson, G.H. Political trust in Iceland: Performance or politics? Stjórnmál 2018, 14, 211-234. [CrossRef]

11. Wei, J.; Han, Y. Pre-Disaster Social Capital and Disaster Recovery in Wenchuan Earthquake-Stricken Rural Communities. Sustainability 2018, 10, 2046. [CrossRef]

12. Gong, X.; Yang, S.; Zhang, M. Not only health: Environmental pollution disasters and political trust. Sustainability 2017, 9, 575. [CrossRef]

13. Reinhardt, G.Y. Disasters, Media, and Political Trust. SSRN Electron. J. 2013. [CrossRef]

14. Kang, S.H.; Skidmore, M.; Rosen, M.A. The Effects of Natural Disasters on Social Trust: Evidence from South Korea. Sustainability 2018, 10, 2973. [CrossRef]

15. Gotham, K.F.; Cheek, W. Post-disaster Recovery and Rebuilding. In The Sage Handbook of the 21st Century City; Sage: London, UK, 2017; pp. 284-285.

16. Han, Z.; Hu, X.; Nigg, J. How Does Disaster Relief Works Affect the Trust in Local Government? A Study of the Wenchuan Earthquake. Risk Hazards Crisis Public Policy 2011, 2, 1-20. [CrossRef]

17. Luo, J.; Shuai, M.; Yang, K. A Sociological Analysis of the "Strong Central, Weak Local" Pattern of Trust in Government: Based on Three Stage Tracking Data after the Wenchuan Earthquake. Soc. Sci. China 2018, 39, 5-25. [CrossRef]

18. Thompson, D.F.; Easton, D. A Framework for Political Analysis. Political Sci. Q. 1968, 83, 632. [CrossRef]

19. Hetherington, M.J. The Political Relevance of Political Trust. Am. Political Sci. Rev. 1998, 92, 791-808. [CrossRef]

20. Almond, G.A.; Verba, S. The Civic Culture; Princeton University Press: Princeton, NJ, USA, 1963.

21. Christeven, T.; Lfegreid, P. Trust in Government: The Relative Importance of Service Satisfaction, Political Factors, and Demography. Public Perform. Manag. Rev. 2005, 28, 487-511. [CrossRef]

22. Kastenholz, H.G. Trust in Cooperative Risk Management: Uncertainty and Scepticism in the Public Mind. Hum. Ecol. Risk Assess. 2014, 14, 433-436. [CrossRef]

23. Fukuyama, F. Trust: The Social Virtues and the Creation of Prosperity; Free Press: New York, NY, USA, 1996; p. 23.

24. Olson, R.S.; Gawronski, V.T. From Disaster Event to Political Crisis: A '5C+A' Framework for Analysis. Int. Stud. Perspect. 2010, 11, 205-221. [CrossRef]

25. Jennings, M. Political Trust and the Roots of Devolution. In Trust and Governance; Russel Sage Foundation: New York, NY, USA, 1988; pp. 219-244. 
26. Shuai, M.; Luo, J.; Liu, J. The Study of the Causes of Government Trust in the "Reverse Deficit": Analysis Based on the Survey Data of Wenchuan Earthquake. Chin. Soc. Sci. Intern. Manuscr. 2016, 38, 58-66. (In Chinese)

27. Citrin, J.; Luks, S. Political Trust Revisited: Déjà Vu All over Again? Cambridge University Press: Oxford, UK, 1998; pp. 9-27.

28. Miller, A.H. Political Issues and Trust in Government: 1964-1970. Am. Political Sci. Rev. 1974, 68, 951-972. [CrossRef]

29. Parry, G. Trust, Distrust and Consensus. Br. J. Political Sci. 1976, 6, 129-142. [CrossRef]

30. Mishler, W.; Rose, R. What Are the Origins of Political Trust? Comp. Political Stud. 2001, 34, 30-62. [CrossRef]

31. Hu, R.; Hu, K.; Wen, Y. Social Capital, Government Performance and Urban Residents' Trust in Government. Sociol. Res. 2011, 1, 96-117.

32. Citrin, J. Comment: The Political Relevance of Trust in Government. Am. Political Sci. Rev. 1974, 68, 973-988. [CrossRef]

33. Citrin, J.; Stoker, L. Political Trust in a Cynical Age. Annu. Rev. Political Sci. 2018, 21, 49-70. [CrossRef]

34. Tyler, T.R. Why People Obey the Law; Yale University Press: New Haven, CT, USA, 1990.

35. Kramer, R.M. Trust and Disrust in Organizations: Emerging Perspectives, Enduring Questions. Annu. Rev. Psychol. 1999, 50, 569-598. [CrossRef] [PubMed]

36. Listhaug, O. The Dynamics of Trust in Politicians. In Citizens and the State; Oxford University Press: Oxford, UK, 1998; pp. 261-297. [CrossRef]

37. Kim, J.Y. "Bowling Together" Isn't a Cure-All: The Relationship between Social Capital and Political Trust in South Korea. Int. Political Sci. Rev. 2005, 26, 193-213. [CrossRef]

38. Norris, P. Introduction: The Growth of Critical Citizens? In Critical Citizens; Oxford University Press: Oxford, UK, 1999; pp. 1-28. [CrossRef]

39. Alesina, A.; Ferrara, E.L. Who Trusts Others? J. Public Econ. 2002, 85, 207-234. [CrossRef]

40. Glaeser, E.L.; Sacerdote, B.; Scheinkman, J.A. The Social Multiplier. SSRN Electron. J. 2002. [CrossRef]

41. Putnam, R.D. Make Democracy Work. In Civic Tradition in Modern Italy; Jiangxi People's Publishing House: Nanchang, China, 2001; p. 195.

42. Norris, P. Democratic Phoenix; Cambridge University Press: Cambridge, UK, 2002. [CrossRef]

43. Uzzi, B. The sources and consequences of embeddedness for the economic performance of organizations. Am. Sociol. Rev. 1996, 61, 674-698. [CrossRef]

44. Luhmann, N. Familiarity, Confidence, Trust: Problems and Alternative. In Trust: Making and Breaking Cooperative Relations; Gambetta, D., Ed.; Oxford University Press: London, UK, 1988; pp. 94-107.

45. Granovetter, M.S. The Strength of Weak Ties. In Social Networks; Elsevier: Amsterdam, The Netherlands, 1977; pp. 347-367. [CrossRef]

46. Yamagishi, T.; Cook, K.S.; Watabe, M. Uncertainty, Trust, and Commitment Formation in the United States and Japan. Am. J. Sociol. 1998, 104, 165-194. [CrossRef]

47. Yamagishi, T.; Yamagishi, M. Trust and commitment in the United States and Japan. Motiv. Emot. 1994, 18, 129-166. [CrossRef]

48. Burt, R.S.; Knez, M. Trust and Third-Party Gossip. In Trust in Organizations: Frontiers of Theory and Research; SAGE Publications Inc.: Thousand Oaks, CA, USA, 1996; pp. 68-89. [CrossRef]

49. Krackhardt, D.; Hanson, J.R. Informal Networks: The Company behind the Chart. In Creative Management and Development; SAGE Publications Inc.: Thousand Oaks, CA, USA, 1993; pp. 191-196. [CrossRef]

50. Marsden, P.; Friedkin, N. Network Studies of Social Influence. In Advances in Social Network Analysis: Research in the Social and Behavioral Sciences; SAGE Publications Inc.: Thousand Oaks, CA, USA, 1994; pp. 3-25. [CrossRef]

51. Wang, Z. Before the Emergence of Critical Citizens: Economic Development and Political Trust in China. Int. Rev. Sociol. 2005, 15, 155-171. [CrossRef]

52. Tang, J.; Huang, S.; Huang, K. Post Disaster Reconstruction Policy and Incentive Exclusion: Taking Collective Action in a Community After the 921 Earthquake as an Example. Political J. 2009, 48, 1-31. (In Chinese)

53. Li, Z.; Luo, J. A Preliminary Study on the Trust Mechanism of Self-Organizational Governance in Rural Communities-Taking a Villager Economic Cooperation Organization as an Example. Manag. World 2012, 10, 83-93. 
54. Job, J. How is trust in government created? It begins at home, but ends in the parliament. Aust. Rev. Public Aff. 2005, 6, 1-23.

55. Tierney, K.J. From the Mar48gins to the Mainstream? Disaster Research at the Crossroads. Annu. Rev. Sociol. 2007, 33, 503-525. [CrossRef]

56. Li, L. Political Trust in Rural China. Modern China 2004, 30, 228-258. [CrossRef]

57. Rong, H. Farmers' petition and the loss of political trust. Sociol. Res. 2007, 3, 39-55.

58. Zhou, F. Ten Years of Tax Sharing System: System and Its Influence. Chin. Soc. Sci. 2006, 6, 100-115. (In Chinese)

59. Liu, H. Research on the Rehabilitation and Reconstruction of Wenchuan Earthquake-stricken Areas. Soc. Sci. Res. 2011, 2, 27-32. (In Chinese)

60. Peters, B.G.; Pierre, J. Handbook of Public Administration; The Jossey-Bass Public Administration Series; SAGE Publications Inc.: Thousand Oaks, CA, USA, 1996; Volume 424, pp. 628-639.

61. Easton, D. A Re-assessment of the Concept of Political Support. Br. J. Political Sci. 1975, 5, 435-457. [CrossRef]

62. Blind, P.K. Building Trust in Government in the Twenty-first Century: Review of Literature and Emerging issues. In Proceedings of the 7th Global Forum on Reinventing Government Building Trust in Government, Vienna, Austria, 26-29 June 2007; UNDESA: New York, NY, USA, 2007; pp. 26-29.

63. Mc Dill, E.L.; Ridley, J.C. Status, Anomia, Political Alienation, and Political Participation. Am. J. Sociol. 1962, 68, 205-213.

64. Abramson, P.R. Political Attitudes in American: Formation and Change; W. H. Freeman and Company Press: San Francisco, CA, USA, 1983; p. 147.

65. Singer, J.D.; Willett, J.B.; Willett, J.B. Applied Longitudinal Data Analysis: Modeling Change and Event Occurrence; Oxford University Press: Oxford, UK, 2003. [CrossRef]

66. Xie, Y. Regression Analysis; Social Science Literature Press: Beijing, China, 2010; pp. 97-98.

67. Kreft, I.G.; De Leeuw, J. Introducing Multilevel Models; SAGE Publications Inc.: Thousand Oaks, CA, USA, 1999.

68. Wen, F. The Theory and Application of the Hierarchical Linear Model; China Light Industry Press: Beijing, China, 2009; p. 260. (In Chinese)

69. Longford, N.T.; Bryk, A.S.; Raudenbush, S.W. Hierarchical Linear Models: Applications and Data Analysis Methods. Contemp. Sociol. 1993, 22, 293. [CrossRef]

70. Luo, J.D. Particularistic Trust and General Trust: A Network Analysis in Chinese Organizations. Manag. Organ. Rev. 2005, 1, 437-458. [CrossRef]

71. Krackhardt, D.; Hanson, J.R. Informal Networks: The Company behind the Chart. Harv. Bus. Rev. 1993, 71, 104-111. [PubMed]

72. Marsden, P.V.; Friedkin, N.E. Network Studies of Social Influence. In Advances in Social Network Analysis; Wasserman, S., Galaskiewicz, J., Eds.; SAGE Publications Inc.: London, UK, 1994.

73. Han, Z. Social Capital and Changes in Post-Disaster Recovery Process: Observations from China After the 2008 Wenchuan Earthquake. In Recovering from Catastrophic Disaster in Asia; Emerald Group Publishing: Bingley, UK, 2017. [CrossRef]

74. Zhen, Z. Individualized Society and Private Community: Criticism Based on Chinese Community Practice. Learn. Pract. 2012, 6, 91-98. (In Chinese)

(C) 2018 by the authors. Licensee MDPI, Basel, Switzerland. This article is an open access article distributed under the terms and conditions of the Creative Commons Attribution (CC BY) license (http://creativecommons.org/licenses/by/4.0/). 